\title{
Cutting efficiency of ProDesign R, Reciproc Blue and WaveOne Gold reciprocating
}

\section{instruments}

\author{
Eficiência de corte dos instrumentos reciprocantes ProDesign R, Reciproc Blue e WaveOne Gold \\ Eficiencia de corte de los instrumentos alternativos ProDesign R, Reciproc Blue y WaveOne Gold
}

Received: 02/16/2021 | Reviewed: 02/22/2021 | Accept: 02/24/2021 | Published: 03/03/2021

\author{
Ana Elisa Aguiar Campos \\ ORCID: https://orcid.org/0000-0003-3844-7652 \\ Faculdade São Leopoldo Mandic, Brazil \\ E-mail:anelisaguiar@hotmail.com \\ Adriana de Jesus Soares \\ ORCID: https://orcid.org/0000-0002-8078-1606 \\ Faculdade de Odontologia de Piracicaba, Brazil \\ E-mail:ajsoares@unicamp.br \\ Ana Grasiela da Silva Limoeiro \\ ORCID: https://orcid.org/0000-0003-4633-720X \\ Faculdade de Ilhéus, Brazil \\ E-mail:grasielalimoeiro@gmail.com \\ Fernanda Tessaro Cintra \\ ORCID: https://orcid.org/0000-0002-7576-1328 \\ Faculdade São Leopoldo Mandic, Brazil \\ E-mail:nandatess@gmail.com \\ Marcos Frozoni \\ ORCID: https://orcid.org/0000-0001-8001-4063 \\ Faculdade São Leopoldo Mandic, Brazil \\ E-mail:marcosfrozoni@gmail.com \\ Gabriel Rocha Campos \\ ORCID: https://orcid.org/0000-0003-3274-527X \\ Faculdade São Leopoldo Mandic, Brazil \\ E-mail:gabrielrochacampos@ig.com.br
}

\begin{abstract}
This study aimed to evaluate, in vitro, the cutting efficiency and time spent for instrumentation of three different heattreated reciprocating systems in simulated straight canals. Forty-five acrylic blocks with a straight simulated root canal with 21 millimeters in length were initially weighed (P1). After weighing the blocks were divided into three groups $(\mathrm{n}=15)$ and each group prepared with the following systems: ProDesign R 25.06 (Bassi/Easy, Belo Horizonte, Brazil), Reciproc Blue25.08 (VDW, Munich, Germany) and Wave one Gold (Dentsply Sirona, Ballaigues, Switzerland). The time spent for the total preparation of each block was recorded. After instrumentation, they were subjected to final weighing (P2). The difference between P1 and P2 determined the amount of material removed (cutting efficiency) by each mechanized system. The statistical analysis was performed by the ANOVA test of each of the variables, for multiple comparisons of means the turkey test was used. As for preparation time, it can be seen that ProDesign $\mathrm{R}$ showed a longer preparation time $(\mathrm{P}<0.5)$ compared to Reciproc Blue and Wave one Gold. Regarding cutting efficiency, there was no statistical difference between the groups $(\mathrm{P}>0.5)$. In straight simulated canals, the type of reciprocating instrument influences the time for instrumentation; however, it shows similar cutting efficiency.

Keywords: Dental pulp cavity; Endodontics; Root canal.
\end{abstract}

\section{Resumo}

Este trabalho teve como objetivo avaliar, in vitro, a eficiência de corte e o tempo gasto para instrumentação de três diferentes sistemas alternativos termicamente tratados em canais retos simulados. Foram pesados inicialmente 45 blocos de acrílico com canal radicular simulado reto com 21 milímetros de comprimento (P1). Após pesagem os blocos foram divididos em três grupos $(\mathrm{n}=15)$ e cada grupo preparado com os seguintes sistemas: ProDesign $\mathrm{R} 25.06$ (Bassi / Easy, Belo Horizonte, Brasil), Reciproc Blue25.08 (VDW, Munique, Alemanha) e Wave um ouro (Dentsply Sirona, Ballaigues, Suíça). Foi registrado o tempo gasto para a preparação total de cada bloco. Após a instrumentação, foram submetidos à pesagem final (P2). A diferença entre P1 e P2 determinou a quantidade de material removido (eficiência de corte) por cada sistema mecanizado. A análise estatística foi realizada pelo teste ANOVA de cada uma das variáveis, para comparações múltiplas de médias foi utilizado o teste do peru. Quanto ao tempo de preparação, pode-se observar que o ProDesign $\mathrm{R}$ apresentou um tempo de preparação maior $(\mathrm{P}<0,5)$ em relação ao Reciproc Blue 
e Wave one Gold. Em relação à eficiência de corte, não houve diferença estatística entre os grupos $(\mathrm{P}>0,5)$. Em canais simulados retos, o tipo de instrumento alternativo influencia o tempo de instrumentação; no entanto, mostra eficiência de corte semelhante.

Palavras chave: Cavidade da polpa dentária; Endodontia; Canal radicular.

\section{Resumen}

Este estudio tuvo como objetivo evaluar, in vitro, la eficiencia de corte y el tiempo empleado para la instrumentación de tres sistemas alternativos tratados térmicamente diferentes en canales rectos simulados. Se pesaron inicialmente cuarenta y cinco bloques acrílicos con un conducto radicular recto simulado de 21 milímetros de longitud (P1). Después de pesar los bloques se dividieron en tres grupos $(n=15)$ y cada grupo se preparó con los siguientes sistemas: ProDesign R 25.06 (Bassi / Easy, Belo Horizonte, Brasil), Reciproc Blue25.08 (VDW, Munich, Alemania) y Wave un oro (Dentsply Sirona, Ballaigues, Suiza). Se registró el tiempo dedicado a la preparación total de cada bloque. Después de la instrumentación, se sometieron a pesaje final (P2). La diferencia entre P1 y P2 determinó la cantidad de material removido (eficiencia de corte) por cada sistema mecanizado. El análisis estadístico se realizó mediante la prueba ANOVA de cada una de las variables, para múltiples comparaciones de medias se utilizó la prueba del pavo. En cuanto al tiempo de preparación, se puede ver que ProDesign $\mathrm{R}$ mostró un tiempo de preparación más largo $(\mathrm{P}<0,5)$ en comparación con Reciproc Blue y Wave one Gold. Con respecto a la eficiencia de corte, no hubo diferencia estadística entre los grupos $(\mathrm{P}>0.5)$. En canales rectos simulados, el tipo de instrumento alternativo influye en el tiempo de instrumentación; sin embargo, muestra una eficiencia de corte similar.

Palabras clave: Cavidad pulpar dental; Endodoncia; Canal raíz.

\section{Introduction}

Cutting efficiency is a property of nickel-titanium (NiTi) endodontic instruments (Plotino et al. 2014) that can be defined as the ability to remove dentine from root canal walls to create a regular space that makes the filling procedure more effective (Peters et al. 2014). Cutting efficiency is a clinically relevant property of NiTi files that are linked to the time spent for instrumentation and facilitates root canal shaping (Vasconcelos et al. 2018). Moreover, cutting ability influences their fracture risk; indeed, endodontic instruments with superior cutting efficiency have less torsional stress and, consequently, less risk of torsional fracture (Di Giuseppe et al. 2015). Acrylics blocks have been used to evaluate the shaping ability of different NiTi systems (Giuliani et al. 2014), due to the full standardization of the canal anatomy (Silva et al. 2015).

ProDesign R (PDR - Bassi/Easy Equipamentos Odontologicos, Belo Horizonte, MG, Brazil) presents an S-shaped cross-section and is manufactured by a unique thermomechanical process that controls the memory of the NiTi (size 25.06) (Alcalde et al. 2017). Wave-One Gold (WOG - Dentsply Maillefer, Ballaigues, Switzerland) is characterized by an offcentered rectangular cross-sectional design and a tip size of 25 with a continuous taper of 7\% (Ozyurek et al.2018). Reciproc Blue (RECB - VWD Munich, Germany) is made of blue heat-treated alloy and presents an S-shaped cross-section with two cutting flutes and tip size of 25 with a continuous $8 \%$ taper over the first three millimeters followed by a regressive taper (De Deus et al. 2017). All instruments work in a counterclockwise reciprocating movement, but with different angles of rotation and speed.

There are no studies regarding the cutting ability of PDR, RECB, and WOG instruments, so this work aimed to study the cutting efficiency of these reciprocating instruments. Therefore, this study compared the cutting ability of three reciprocating endodontic instruments chosen because of their similarities in the reciprocating movement and different thermal treatments that have been widely used to improve the mechanical properties (De Deus et al. 2017).

The null hypotheses tested were as follow:

(i) there are no differences between the instruments tested regarding their cutting ability;

(ii) there are no differences in the time taken to prepare simulated straight canals in acrylic blocks. 


\section{Methodology}

Forty-five acrylic blocks (IM do Brasil, São Paulo - Brazil) were used with straight canals of $21 \mathrm{~mm}$ in length and initial diameter \#10. These blocks were fixed in the same position and then were prepared with $\mathrm{K} \# 10$ and \#15 files (MailleferDentsply, Ballaigues / Switzerland) to obtain a standard initial diameter \# 15. Before and after each cutting session, the acrylic blocks were ultrasonically cleaned in a bath (Unique Ind. And Com, by Prod. Elet. LTDA, USC 1400, São Paulo / SP / Brazil) for 1 hour, and then thoroughly dried in an oven (Odontobrás Ind. And Com. Equip. Med. LTDA, ECB 1.3 digital, Ribeirão Preto / SP / Brazil) at 37 degrees for 24 hours.

Then, the initial weigh (P1) was measured on the precision scale (OHAUS Corp, Adventurer USA) to a resolution of $0.1 \mathrm{mg}$. The weight loss of the acrylic blocks quantified the cutting efficiency of the instrument during the test. The blocks were randomly divided into three groups $(\mathrm{n}=15)$ according to the system used during the instrumentation: G1: ProDesign $\mathrm{R}$ \#25.06(PDR), G2: Reciproc Blue \#25.08(RECB); G3: Wave One Gold \#25.07(WOG). The blocks were fixed in a metal vise so that the canal was parallel to the floor.

Before the instrumentation, $0.1 \mathrm{~mL}$ of water-soluble gel (K-Med, Cimed, Pouso Alegre-Brazil) was applied with a $1 \mathrm{~mL}$ syringe and $20 \times 55 \mathrm{~mm}$ disposable hypodermic needle (Descarpack, São Paulo-Brazil) that was inserted $3 \mathrm{~mm}$ up to the working length (WL). The instrumentation was performed with an endodontic motor (X-smart plus, Dentsply, Ballaigues Switzerland) with the files corresponding to each group, making penetration and traction movements with a maximum of $3 \mathrm{~mm}$ of amplitude. After the file reached the first third, making an in-and-out movement in the apical direction, it was removed from the canal, cleaned with sterile gauze moistened with distilled water.

The canal was irrigated again (to ensure debris removal from the acrylic blocks) with $1 \mathrm{~mL}$ of distilled water using a peristaltic pump (MS Tecnopon instrumentation Piracicaba-Brazil) and applied $0.1 \mathrm{~mL}$ of water-soluble gel in the same conditions described above for instrumentation of the second third. The preparation proceeded in this way until the file reached the measurement of $21 \mathrm{~mm}$. Each instrument was used once. At the end of the protocols, each sample was irrigated with $5 \mathrm{~mL}$ of distilled water. The total irrigant volume for each sample was $20 \mathrm{~mL}$.

After canal preparation the blocks were again washed in an ultrasonic bath of distilled water for 1 hour to remove any residual debris. Prior to the second weight (P2) the acrylic blocks were dried in an oven at 37 degrees for 24 hours. The cutting efficiency was assessed by the loss of mass of the blocks after the instrumentation (P1-P2) (Keskin et al. 2018). During the preparation of the blocks, a camera from a Samsung Galaxy S8 cell phone (Samsung Electronics da Amazônia LTDA, Manaus / Amazonas / Brazil) set at 10cm of distance from the block and the entire preparation time was recorded. The film was edited using the Avidemux program (www.avidemux.org) counting only the time that the file was effetively acting within the canal. The mass loss of the block was measured by the difference of weight between P1 - P2, and the time spent for the file finish the instrumentation of each block were noted, tabulated and statistical analysis was performed.

\section{Results}

The statistical analysis used the ANOVA test for each variable, and for multiple comparisons of means, the turkey test was used. Values of less than 5\% were considered significant differences. Table 1 shows the average time spent in seconds (sec) to prepare the simulated canal. 
Table 1. Comparison of time spent for instrumentation.

\begin{tabular}{lll}
\hline Groups & \multicolumn{2}{c}{ Average (sec) } \\
\hline ProDesign R & 59,1 & A \\
\hline Reciproc Blue & 45,0 & B \\
Wave One gold & 43,2 & B \\
\hline
\end{tabular}

*Different letters in the same column represent statistically significant difference between groups. Source: Authors.

The average time spent for instrumentation in the ProDesign $\mathrm{R}$ group was higher than the other groups, differing significantly from them. The groups did not differ on the amount of removed resin (Figure 1).

Figure 1. Superimposition of pre- and post-preparation images (A) ProDesign R, (B) Reciproc Blue and (C) WaveOne Gold.

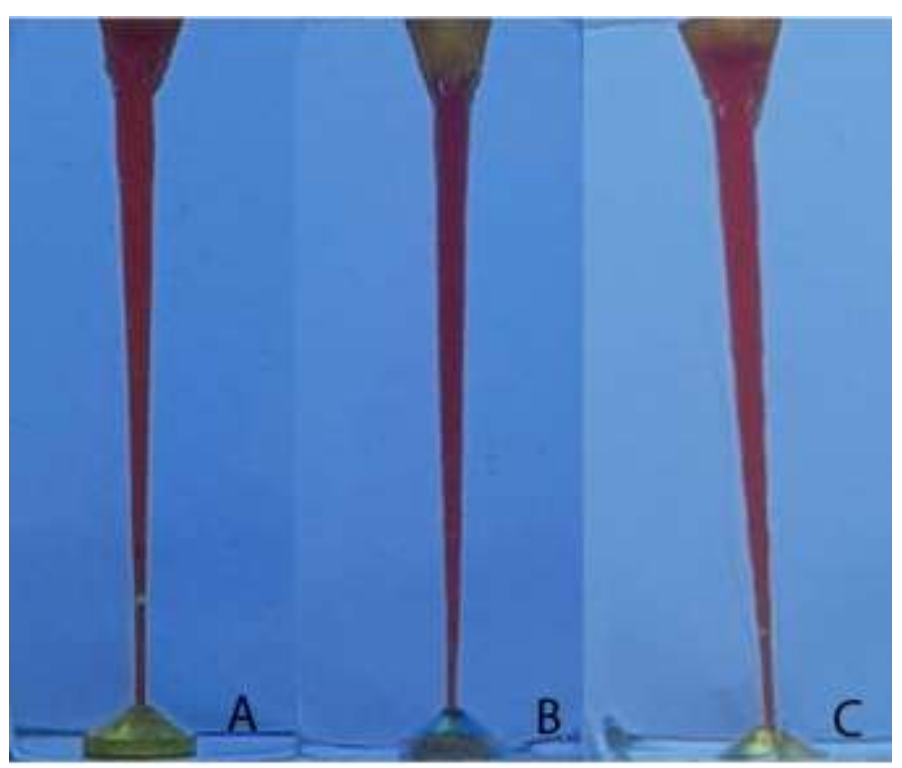

Source: Authors.

Regarding the weight difference of the blocks, there was no statistical difference as can be seen in Table 2.

Table 2 - The weight difference of the 3 groups in milligrams (mg), standard deviation (SD) and the difference of these values in percentage $(\%)$.

\section{Groups}

\begin{tabular}{lccccc}
\hline PDR & 2.508 & 2.499 & $0,009 \mathrm{~b}$ & $0,007 \pm 0,012$ & 0,038 \\
RECB & 2.513 & 2.504 & $0,009 \mathrm{~b}$ & $0,007 \pm 0,012$ & 0,038 \\
WOG & 2.544 & 2.534 & $0,010 \mathrm{~b}$ & $0,008 \pm 0,013$ & 0,038 \\
\hline
\end{tabular}

The values are mean $\pm \mathrm{SD}$. SD, standard deviation.

*Equal letters in the same column represent no statistically significant difference between groups.

Source: Authors. 


\section{Discussion}

This study evaluated the cutting ability of three reciprocating instruments with the same tip (\#25) and a different manufacturing process. Concerning taper and cross-sectional design, the files investigated in this study present some differences. ProDesign R and Reciproc Blue presents the same S-shaped cross-section and taper 0.06 and 0.08, respectively. WaveOne Gold presents an off-centered rectangular cross-sectional design with a continuous taper of $7 \%$. Regardless of the differences in the alloy's heat treatment and tapers, there were no statistical differences in the instruments' cutting ability.

The use of simulated straight canals in acrylic blocks guarantees hardness homogeneity of the samples and prevents the anatomy from interfering with the results (Keskin et al. 2018). However acrylic blocks do not exhibit the same properties as the dentin and the heat generation by the instrumentation may soften the resin material, leading to binding of cutting blades, and separation of the instrument (Kum et al. 2000, Yoo et al. 2012), some studies have discouraged testing on human and bovine teeth because of hardness and variable patterns (Gambarini et al.2016, Ha et al. 2017). All blocks were fixed in the same position to avoid differences the position of the file penetration during canal preparation-as well as to allow better visualization of the working length.

Cutting efficiency is one of the properties of nickel-titanium (NiTi) instruments in endodontics (Plotino et al. 2014) and can be defined as the ability to remove dentin from the root canal walls to create a tapered progressive pattern to allow a more homogeneous root canal filling. Cutting efficiency has been investigated using different methods: weight loss (Haikel et al. 2017), debris generated during instrumentation (Wan et al. 2010), measuring the maximum penetration depth of the instrument into the canal (Schafer et al. 2008), and preparation time (Burklein et al. 2013). Among different evaluation methods, weight loss gives the most reliable quantitative measurement (Vinothkumar et al. 2007). Several studies comparing the cutting efficiency of reciprocating systems reported similar results, regardless of the cross-sectional design, taper, and alloy (Plotino et al. 2014, Elashiry et al. 2020, Haikel et al. 2017, Wan et al. 2010, Schafer et al. 2008, Burklein et al. 2013, Vinothkumar et al. 2007). The observation that instruments with S-shape cross-section were associated with an enhanced cutting efficiency (Plotino et al. 2014, Schafer eta al. 2006) was not confirmed in this investigation. We have found no differences between the groups.

Ozyurek et al. 2017 compared the Reciproc (VDW, Munich, Germany), HyFlex EDM (Coltene/Whaledent AG, Altstatten, Switzerland) and WaveOne Gold NiTi files' shaping ability and reported that all of the tested NiTi files caused various levels of resin removal. However, the WOG and HyFlex EDM NiTi files were found to cause a lower level of resin removal than the Reciproc NiTi files did and argued that this was because of the rectangular cross section provides better management of a curved canal than the S-shaped cross section.

In this study, the weight differences of blocks before and after instrumentation means the amount of material removed by the different files, which is related to their cutting efficiency. Although the files have the same tip (\#25) and varied tapers, on the D16 the diameters are the same, thus justifying the same wear and tear.

It has been suggested that the heat treatment of the alloy may reduce cutting ability due to the plastic deformation and disruption of cutting edges during use (Shen et al. 2013). However, considering that ProDesign R instruments are manufactured from a more flexible alloy, the restoring force might be reduced, and the instrument may remain more centered in the canal than the other instruments during use (Vasconcelos et al. 2018). In this study, the preparation time was considered when the instrument reached the apical foramen of the simulated canal. PDR had a significantly longer preparation time than RECB and WOG to shape the canals, which could be explained by the heat treatment to which the file is subjected, that gives the file greater flexibility (Santos et al. 2019). Heat treatment is a significant factor in the qualification of instruments and has been increasingly used (Kim et al. 2012). PDR instruments are found mainly in the martensitic phase, which provides more flexibility and resistance to cyclic fatigue than those manufactured with Blue and Gold treatments (Alcalde et al. 2018). WOG 
and RECB instruments, when compared to their predecessors WaveOne and Reciproc, maintained shaping abilities well and were safe (Burklein et al. 2019).

As the reason for the higher time to finish the instrumentation by PDR files compared with WOG and RECB files, we believe that the alloy that PDR files are made of are more flexible, and consequently, they are capable of better adapting to the original shape of the canal, spending more time to reach the working length. PDR has a smaller area compared to RECB, and WOG (Vahid et al. 2009).

The WOG cross-section improves safety, increases cutting efficiency, and provides more chip space to auger debris coronally, as compared to the original Primary WaveOne file (Dentsply, 2014). The WOG file is at least 80\% more flexible; and $23 \%$ more efficient, compared to its Primary WaveOne M-Wire predecessor due to its best treatment, reducing taper lock and the screw-effect (Santos et al. 2019). However, considering that ProDesign R instruments are manufactured from a more flexible alloy, the restoring force might be reduced, and the instrument may remain more centered in the canal than the other instruments during use.

RECB has a thermomechanical oxide surface layer alloy obtained through a proprietary-specific manufacturing process (De Deus et al. 2017). When compared to Reciproc, demonstrating improved flexibility and fatigue resistance can play an essential role in improving root canal cleaning and shaping procedures (Maniglia-Ferreira et al. 2017). Despite the proprietary blue heat treatment, which modifies the molecular structure, which gives the RCB instruments more strength and flexibility than the Reciproc instrument system, the ability of RCB to reach the full working length is not as good as that of Reciproc, although the difference was not statistically significant (Adiguzel, Tufenkci, 2018).

Similar to this study, Keskin et al. 2018 compared WOG and RECB using simulated curved canals of resin blocks but with different results: WOG showed the best performance regarding canal centering ratio and the amount of canal transportation at the apical level suggesting that the file characteristics such as the surface treatment, cross-sectional design or the taper have more influence on the file performance rather than the motion kinematics (Elashiry et al. 2020). Modifications on cross-section design, surface treatment, and manufacturing processes have been proposed for enhancing the cutting efficiency and fatigue resistance of NiTi rotary instruments (De Deus et al. 2017).

The different weight of the blocks being statistically insignificant can be explained by the fact that RECB has taper 08 from D0 to D3 and tapers 04 from D4 to D16, and WOG has taper 07 from D0 to D3, taper 06 from D4 to D8, and tapers 03 from D9 to D16, thus offsetting the differences from the first tapers. ProDesign R presents a constant 0.06 taper in its active part, although this study suggests that the total volume of the instrument is very close to that of REC and WOG. The crosssection configuration of each instrument $5 \mathrm{~mm}$ from the tip showed the smallest area to PDR followed by RECB and WOG. At $3 \mathrm{~mm}$ PDR showed the smallest area followed by WOG and RECB (Elashiry et al. 2020).

\section{Conclusions}

All tested instruments had the same cutting efficiency. ProDesign R had a significantly longer time than Reciproc Blue and Wave one Gold to shaping the canal. Further studies are required to evaluate these instruments' cutting efficiency using other methodologies such as extracted teeth.

\section{Conflict of interest}

"No potential conflict of interest relevant to this article was reported".

\section{Acknowledgements}

The authors deny any conflicts of interest. 


\section{References}

Adiguzel, M., \& Tufenkci, P. (2018). Comparison of the ability of Reciproc and Reciproc Blue instruments to reach the full working length with or without glide path preparation. Restor Dent Endod, 43:e41.

Alcalde, M. P., Duarte, M. A. H., \& Bramante, C. M. (2018). Cyclic fatigue and torsional strength of three different thermally treated reciprocating nickeltitanium instruments. Clin Oral Investig, 22:1865-1871.

Alcalde, M. P., Tanomaru-Filho, M., \& Bramante, C. M. (2017). Cyclic and Torsional Fatigue Resistance of Reciprocating Single Files Manufactured by Different Nickel-titanium Alloys. J Endod, 43:1186-1191.

Burklein, S., Benten, S., \& Schafer, E. (2013). Shaping ability of different single-file systems in severely curved root canals of extracted teeth. Int Endod J 46:590-597.

Bürklein, S., Flüch, S., \& Schäfer, E. (2019). Shaping ability of reciprocating single-file systems in severely curved canals: WaveOne and Reciproc versus WaveOne Gold and Reciproc blue. Odontology, 107:96-102.

De-Deus, G., Silva, E. J., Vieira, \& V. T. (2017). Blue thermomechanical treatment optimizes fatigue resistance and flexibility of the reciproc files. J Endod, 43:462-466.

Dentsply Maillefer engineering and testing, Ballaigues, Switzerland, 2014.

Di Giuseppe, I., Di Giuseppe, D., Malagnino, V. A., et al. (2015). Conditioning of root canal anatomy on static and dynamics of nickel-titanium rotary instruments. J Endod, 29:58-64.

Elashiry, M. M., Saber, S. E., \& Elashry, S. H. (2020). Comparison of Shaping Ability of Different Single-File Systems Using Microcomputed Tomography. Eur J Dent, 14:70-76.

Gambarini, G., Rubini, A. G., \& Sannino, G. (2016). Cutting efficiency of nickel-titanium rotary and reciprocating instruments after prolonged use. Odontology, 104:77-81.

Giuliani, V., Di Nasso, L., Pace, R., et al. (2014). Shaping ability of WaveOne primary reciprocating files and ProTaper system used in continuous and reciprocating motion. J Endod, 40:1468-1471.

Ha, J. H., Kwak, S. W., \& Sigurdsson, A. (2017). Stress Generation during Pecking Motion of Rotary Nickel-titanium Instruments with Different Pecking Depth. J Endod, 43:1688-1691.

Haikel, Y., Serfaty, R., \& Lwin, T. T. (1996). Measurement of the cutting efficiency of endodontic instruments: a new concept. J Endod, 22:651-656.

Keskin, C., Demiral, M., \& Saryılmaz, E. (2018). Comparison of the shaping ability of novel thermally treated reciprocating instruments. Restor Dent Endod, 43:e15.

Kim, H. C., Kwak, S. W., \& Cheung, G. S. P. (2012). Cyclic fatigue and torsional resistance of two new nickel titanium instruments used in reciprocation motion reciproc versus WaveOne. J Endod, 38:541-544.

Kum, K. Y., Sp.ngberg, L., Cha, B. Y., Jung, I. Y, Lee, S. J., \& Lee, C. Y. Shaping ability of three Profile rotary instrumentation techniques in simulated resin root canals. J Endod 2000; 26:719-723.

Maniglia-Ferreira, C., de Almeida Gomes, F., \& Ximenes, T. (2017). Influence of reuse and cervical preflaring on the fracture strength of reciprocating instruments. Eur J Dent, 11:41-47.

Ozyurek, T., Uslu, G., \& Gundogar, M. (2018) Comparison of cyclic fatigue resistance and bending properties of two reciprocating nickel-titanium glide path files. Int Endod J, 51:1047-1052

Ozyurek, T., Yılmaz, K., \& Uslu, G. (2017). Shaping Ability of Reciproc, WaveOne GOLD, and HyFlex EDM Single-file Systems in Simulated S-shaped Canals. J Endod, 43:805-809.

Peters, O. A., Morgental, R. D., Schulze, K. A., et al. (2014). Determining cutting efficiency of nickel-titanium coronal flaring instruments used in lateral action. Int Endod J, 47:505-513.

Plotino, G., Giansiracusa Rubini, A., Grande, N. M., et al. (2014). Cutting efficiency of Reciproc and WaveOne reciprocating instruments. J Endod, 40:12281230 .

Santos, C. B., Simoes-Carvalho, M., \& Perez, R. (2019). Torsional fatigue resistance of R-Pilot and WaveOne Gold Glider NiTi glide path reciprocating systems Int Endod J, 52:874-879.

Schafer, E., Erler, M., \& Dammaschke, T. (2006). Comparative study on the shaping ability and cleaning efficiency of rotary Mtwo instruments: part 2. Cleaning effectiveness and shaping ability in severely curved root canals of extracted teeth. Int Endod J, 39:203-212.

Schafer, E., \& Oitzinger, M. (2008). Cutting efficiency of five different types of rotary nickel-titanium instruments. J Endod, 34:198-200.

Shen, Y., Zhou, H. M., \& Zheng, Y. F. (2013). Current challenges and concepts of the thermomechanical treatment of nickel-titanium instruments. J Endod, 39:163-172.

Silva, E. J., Tameirão, M. D., Belladonna, F. G., et al. (2015). Quantitative transportation assessment in simulated curved canals prepared with an adaptive movement system. J Endod, 41:1125-1129. 
Research, Society and Development, v. 10, n. 3, e1710313028, 2021

(CC BY 4.0) | ISSN 2525-3409 | DOI: http://dx.doi.org/10.33448/rsd-v10i3.13028

Vahid, A., Roohi, N., \& Zayeri, F. (2009). A comparative study of four rotary NiTi instruments in preserving canal curvature, preparation time and change of working length. Aust Endod J, 35:93-97.

Vasconcelos, R. A., Arias, A., \& Peters, O. A. (2018). Lateral and axial cutting efficiency of instruments manufactured with conventional nickel-titanium and novel gold metallurgy. Int Endod J, 51:577-583.

Vinothkumar, T. S., Miglani, R., \& Lakshminarayananan, L. (2007). Influence of deep dry cryogenic treatment on cutting efficiency and wear resistance of nickel-titanium rotary endodontic instruments. J Endod, 33:1355-1358.

Wan, J., Rasimick, B. J., \& Musikant, B. L. (2010). Cutting efficiency of 3 different instrument designs used in reciprocation. Oral Surg Oral Med Oral Pathol Oral Radiol Endod, 109:82-85.

Yoo, Y. S., \& Cho, Y. B. A comparison of the shaping ability of reciprocating NiTi instruments in simulated curved canals. Restor Dent Endod 2012; 37: 220-7.) 